\title{
What chances do children have against COVID-19? Is the answer hidden within the thymus?
}

\author{
Hatice Güneş ${ }^{1} \cdot$ Serpil Dinçer $^{1} \cdot$ Can Acıpayam $^{2} \cdot$ Sadık Yurttutan $^{3}$ (D) • Mehmet Yaşar Özkars ${ }^{4}$ \\ Received: 5 May 2020 / Revised: 13 September 2020 / Accepted: 9 October 2020 / Published online: 13 October 2020 \\ (C) Springer-Verlag GmbH Germany, part of Springer Nature 2020
}

\begin{abstract}
A new type of coronavirus named as SARS-CoV-2 pandemic has begun to threaten human health. As with other types of coronaviruses, SARS-CoV-2 affects children less frequently, and it has been observed that the disease is mild. In the pathogenesis of a standard viral infection, the pathogen's contact with the mucosa is initially followed by an innate immunity response. T cells are the primary decisive element in adaptive immunity capability. For this reason, the adaptive immune response mediated by the thymus is a process that regulates the immune response responsible for preventing invasive damage from a virus. Regulatory $\mathrm{T}$ cells (T-reg) are active during the early periods of life and have precise roles in immunomodulation. The thymus is highly active in the intrauterine and neonatal period; it begins to shrink after birth and continues its activity until adolescence. The loss of T-reg function by age results in difficulty with the control of the immune response, increased inflammation as shown in coronavirus disease (COVID-19) as an inflammatory storm. Also, the thymus is typically able to replace the T cells destroyed by apoptosis caused by the virus. Thymus and T cells are the key factors of pathogenesis of SARS-CoV-2 in children.

Conclusion: We speculated that thymus activity and $\mathrm{T}$ lymphocyte function in children protect them against the virus effects. Stimulating and preventing the inhibition of the thymus can be possible treatment components against COVID-19.
\end{abstract}

What is Known:

- The SARS-CoV-2 infection does not often progress with an invasive clinic in children.

- Thymus activity and Tlymphocyte functions are highly active in children.

What is New:

- Effective thymus activity and T lymphocyte function in children protect them against the invasive SARS-CoV-2 infection.

- Stimulating and preventing the inhibition of the thymus can be possible treatment components against COVID-19.

Keywords Children · Coronavirus · COVID-19 · Immunosenescence · SARS-CoV-2 · Thymus

Communicated by Nicole Ritz

Sadik Yurttutan

dryurttutan@gmail.com

Hatice Güneș

drhaticegunes@gmail.com

Serpil Dinçer

drserpildincer@gmail.com

Can Acipayam

cacipayam@hotmail.com

Mehmet Yaşar Özkars

myozkars@hotmail.com
1 Department of Pediatrics, Faculty of Medicine, Kahramanmaras Sutcu Imam University, Kahramanmaras, Turkey

2 Department of Pediatric Hematology and Oncology, Faculty of Medicine, Kahramanmaras Sutcu Imam University,

Kahramanmaras, Turkey

3 Department of Pediatrics Division of Neonatology, Faculty of Medicine, Kahramanmaras Sutcu Imam University, Avsar Campus, 46100 Kahramanmaras, Turkey

4 Department of Pediatric Allergy and Immunology, Faculty of Medicine, Kahramanmaras Sutcu Imam University, Kahramanmaras, Turkey 


$\begin{array}{ll}\text { Abbreviations } & \\ \text { ACE2 } & \text { Angiotensin-converting enzyme-2 } \\ \text { CD 26 } & \text { Cluster of differentiation 26 } \\ \text { COVID-19 } & \begin{array}{l}\text { 2019 coronavirus disease } \\ \text { Granulocyte macrophage } \\ \text { GM-CSF }\end{array} \\ \text { colony-stimulating factor } \\ \text { IL-7 } & \text { Interleukin-7 } \\ \text { MERS-CoV } & \text { Middle East respiratory syndrome } \\ \text { OSM } & \text { Oncostatin M } \\ \text { RNA } & \text { Ribonucleic acid } \\ \text { SARS-CoV-2 } & \begin{array}{l}\text { Severe acute respiratory } \\ \text { syndrome coronavirus 2 }\end{array} \\ \text { TGF } & \text { Transforming growth factor } \beta \\ \text { T-reg } & \text { Regulatory T cells }\end{array}$

A new type of coronavirus named as SARS-CoV-2 has begun to threaten human health and marked its first appearance in December 2019 in the capital of China's Hubei Province, Wuhan. In just 2 months, the virus had spread to every continent (except Antarctica) and became the cause for a pandemic. The number of confirmed cases worldwide has 3,407,747 and including 238,198 deaths, reported to the World Health Organization by date 04 May [1].

Coronaviruses are enveloped, positive sense, singlestranded ribonucleic acid (RNA) viruses that measure $80-220 \mathrm{~nm}$ in size and are responsible for $15 \%$ of common cold cases in humans while also causing serious infections such as croup, bronchiolitis, and pneumonia. The coronaviruses have many types that cause endemic infections; with the addition of the 2003 SARS-associated coronavirus (SARS-CoV) and the 2012 Middle East respiratory syndrome (MERS-CoV), coronaviruses have been responsible for many deaths and continue to considerably impact public health [2]. While having a high mortality rate in adults, the SARS-CoV and MERS-CoV have not caused deaths in pediatric patients. Including the SARS$\mathrm{CoV}-2$, it has been shown that coronavirus infections in children present in mild forms [3]. Historically, outbreaks such as the Spanish flu, paralytic polio, and influenza have similarly been shown to have mild effects on children [4]. Scientists researched why children and young people were protected in the 3 recent coronavirus epidemics; they speculated that less outdoor activity, international travel, and lower angiotensin-converting enzyme2 (ACE2) receptor expression in children were primarily responsible [4].

In the pathogenesis of a standard viral infection, the pathogen's contact with the mucosa is initially followed by an innate immunity response (e.g., macrophage, antigen presenting and natural killer cell) and the objective is to eliminate the pathogen in the initial stage. Subsequently, adaptive immunity comes into play and is responsible for the elimination of infected cells, activation of the antibody response, and production of memory $\mathrm{T}$ cells.

$\mathrm{T}$ cells are the primary decisive element in adaptive immunity capability. For this reason, the adaptive immune response mediated by the thymus is a process that regulates the immune response responsible for preventing invasive damage from a virus. Therefore, the thymus is the most influential organ in the transmission of viral disease [5]. The thymus is highly active in the intrauterine and neonatal period; it begins to shrink after birth and continues its activity until adolescence. The thymus decreases in both function and activity as the person ages [6]. Thymic involution and the gradual decrease in $T$ cell count and ability with age are together termed as immunosenescence. With immunosenescence, the person becomes susceptible to autoimmune diseases, infections, and cancer $[7,8]$. Regulatory $\mathrm{T}$ cells (T-reg) are active during the early periods of life and have precise roles in immunomodulation. It has been shown that T-reg activity decreases with immunosenescence [9]. The loss of T-reg function results in difficulty with the control of the immune response, increased inflammation, and a tendency to autoimmunity.

Clinic and pathological examination of coronavirus disease (COVID-19) cases showed a cytokine storm associated with a disregulated immune response, which ultimately resulted in extensive tissue damage. This tissue damage is caused by an out-of-control immune response induced by the virus [10]. The primary reason for the clinical picture being seen in this manner in patients of ages 50 and up may be due to a deficient, irregular, and uncontrollable antiviral response as a result of thymus involution and immunosenescence.

Important factors in achieving an adequate immune response are an increase in thymus activity and $\mathrm{T}$ cell action along with immune system coordination. Severe cases of COVID-19 consist of lymphopenia, especially $\mathrm{T}$ cell loss [11]. The primary mechanism responsible for lymphopenia is cluster of difference 26 (CD 26) marked T cells being targeted by the coronavirus, resulting in apoptosis of these cells and impairment of the immune system $[12,13]$. The thymus is typically able to replace the $\mathrm{T}$ cells destroyed by apoptosis; however, this is not consistent in older patients. Greater thymus activity and $\mathrm{T}$ lymphocyte function in children protect them against autoimmune disease, viral infections, and cancer. Research has shown an increased rate of childhood mortality with reduced thymus size [14].

When examining the critical COVID-19 cases in the literature, the male gender seems to be more common; this is speculated to be due to greater tobacco use and angiotensin- 
Table 1 Treatment options that can prevent thymic atrophy or stimulate thymus

\begin{tabular}{|c|c|c|}
\hline Molecule/therapy option & Treatment & Effects \\
\hline Zinc & Oral supplement & $\begin{array}{l}\text { Lowers age-associated thymic atrophy with partial recovery } \\
\text { of lymphocyte functions, as measured by mitogen } \\
\text { responsiveness and NK cell activity on mice, and } \\
\text { serves as a co-factor of thymulin which is associated } \\
\text { with both intrathymic and extrathymic T cell differentia- } \\
\text { tion }\end{array}$ \\
\hline Antioxidants & $\begin{array}{l}\text { Vitamin } \mathrm{E} \text {, high-dose vitamin } \mathrm{C} \text { and } \mathrm{N} \text {-acetyl cys- } \\
\text { teine }\end{array}$ & Reduces thymic atrophy \\
\hline IL-7 & Recombinant human IL-7 & $\begin{array}{l}\text { Increased TCR diversity in clinical studies in humans, } \\
\text { in vitro proliferation of peripheral T cells and } \\
\text { increased thymic output in aged mice }\end{array}$ \\
\hline Glucocorticoids & Inhibition of glucocorticoids & $\begin{array}{l}\text { Glucocorticoids reduce thymic cell count during } \\
\text { Salmonella typhimurium and Francisella tularensis } \\
\text { infections in mice; therapies with thymopoeitic } \\
\text { potential are known to reduce GCs. }\end{array}$ \\
\hline Leptin & & $\begin{array}{l}\text { It reduces thymic atrophy, increases intrathymic IL-7, } \\
\text { and decreases pro-inflammatory cytokine release } \\
\text { in mice, but not all conditions are suitable for adminis- } \\
\text { tration. }\end{array}$ \\
\hline Keratinocyte growth factor & & Increases thymic output and naive $\mathrm{T}$ cell pool in aged mice. \\
\hline $\begin{array}{l}\text { Ghrelin, an appetite-stimulant hor- } \\
\text { mone }\end{array}$ & & $\begin{array}{l}\text { Improvement in thymocyte numbers, thymic output, } \\
\text { and } T \text { cell activation in aged mice }\end{array}$ \\
\hline
\end{tabular}

converting enzyme-2 (ACE2) receptor expression [15]. The literature also shows that thymic involution is more apparent in males compared to females [16]. This difference in thymic involution indicates that males face a greater extent of immunosenescence. We believe this mechanism might be responsible for clinical worsening in males. We also believe that the reason females experience a relatively lower rate of thymic involution is due to their higher levels of leptin; some studies have shown that leptin protects the thymus from atrophy $[6,17]$.

In conclusion, stimulating and preventing the inhibition of the thymus can be possible treatment components against COVID-19 infections. In this context, potential thymusstimulating cytokines include human interleukin-7 (IL-7), keratinocyte growth factor, thymic stromal lymphopoietin, keratinocyte growth factor, leptin, and molecules with antioxidant activity such as high-dose vitamin $\mathrm{C}$, oral zinc supplements, luteinizing hormone-releasing hormone receptor antagonist, ghrelin, and systemic administration of a fusion product of granulocyte macrophage colony-stimulating factor (GM-CSF) (Table 1) [6, 18]. In addition, agents that inhibit thymus suppressing cytokines can also be used; these include transforming growth factor $\beta$ (TGF), oncostatin M (OSM), and leukemia inhibitory factor [6].
Authors' contributions Authors' contributions All authors contributed to the study conception and design. Literature research, data collection, and analysis were performed by Hatice Güneş, Serpil Dinçer, Can Acıpayam, Sadık Yurttutan, and Mehmet Yaşar Özkars. The first draft of the manuscript was written by Hatice Güneș, Serpil Dinçer, Can Acıpayam, Sadık Yurttutan, and Mehmet Yaşar Özkars, and all authors commented on previous versions of the manuscript. Both the authors approved the final manuscript as submitted and agree to be accountable for all aspects of the work.

\section{Compliance with ethical statements}

Conflict of interest The authors declare that they have no conflict of interest.

Ethical approval This article does not contain any studies with human participants or animals performed by any of the authors.

\section{References}

1. World Health Organizatian (WHO). Coronavirus disease 2019 (COVID-19) situation dashboard. https://covid19.who.int/. Accessed 04 May 2020 
2. Freeman MC, Denison MR (2019) Coronaviruses. In: Kliegman RM, Stanton BF, St Geme JW, Schor NF (eds) Nelson textbook of pediatrics, vol 2, 21st edn. Elsevier, Philadelphia, pp 1742-1745

3. Cao Q, Chen YC, Chen CL, Chiu CH (2020) SARS-CoV-2 infection in children: transmission dynamics and clinical characteristics. J Formos Med Assoc 119:670-673

4. Lee PI, Hu YL, Chen PY, Huang YC, Hsueh PR (2020) Are children less susceptible to COVID-19? J Microbiol Immunol Infect 20:1684-1182

5. Savino W (2006) The thymus is a common target organ in infectious diseases. PLoS Pathog 2:62

6. Gruver AL, Hudson LL, Sempowski GD (2007) Immunosenescence of ageing. J Pathol 211:144-156

7. Gruver AL, Hudson LL, Sempowski GD (2009) Immunosenescence of ageing. J Transpl Int 22:1041-1050

8. Chinn IK, Blackburn CC, Manley NR, Sempowski GD (2012) Changes in primary lymphoid organs with aging. Semin Immunol 24:309-320

9. Coder B, Su DM (2015) Thymic involution beyond T-cell insufficiency. Oncotarget. 6:21777-21778

10. Qin C, Zhou L, Hu Z et al (2020) Dysregulation of immune response in patients with COVID-19 in Wuhan, China. Clin Infect Dis $12: 248$

11. Shi H, Han X, Jiang $N$ et al (2020) Radiological findings from 81 patients with COVID-19 pneumonia in Wuhan, China: a descriptive study. Lancet Infect Dis

12. Chu H, Zhou J, Wong BH et al (2014) Productive replication of Middle East respiratory syndrome coronavirus in monocyte- derived dendritic cells modulates innate immune response. Virology. 454-455:197-205

13. Zhou J, Chu H, Li C, Wong BHY, Cheng ZS, Poon VKM, Sun T, Lau CCY, Wong KKY, Chan JYW, Chan JFW, To KKW, Chan KH, Zheng BJ, Yuen KY (2014) Active replication of Middle East respiratory syndrome coronavirus and aberrant induction of inflammatory cytokines and chemokines in human macrophages: implications for pathogenesis. J Infect Dis 209:1331-1342

14. Garly ML, Trautner SL, Marx C, Danebod K, Nielsen J, Ravn H, Martins CL, Balé C, Aaby P, Lisse IM (2008) Thymus size at 6 months of age and subsequent child mortality. J Pediatr 153:683688

15. Zhou F, Yu T, Du R et al (2020) Clinical course and risk factors for mortality of adult inpatients with COVID-19 in Wuhan, China: a retrospective cohort study. Lancet. S0140-6736:30566-30563

16. Drabkin MJ, Meyer JI, Kanth N, Lobel S, Fogel J, Grossman J, Krumenacker JH (2018) Age-stratified patterns of thymic involution on multidetector CT. J Thorac Imaging 33:409-416

17. Zhang Y, Chua S Jr (2017) Leptin function and regulation. Compr Physiol 8:351-369

18. Majumdar S, Nandi D (2018) Thymic atrophy: experimental studies and therapeutic interventions. Scand J Immunol 87:4-14

Publisher's note Springer Nature remains neutral with regard to jurisdictional claims in published maps and institutional affiliations. 